\title{
COMMENT A R Y
}

Presented in part at the Connective Tissue Oncology Society Meeting, Vancouver, British Columbia, Canada, November 12-14, 1998; and the American Academy of Orthopaedic Surgeons, Anaheim, California, February 4-8, 1999.

Address for reprints: J. Sybil Biermann, M.D., 7304 Cancer Center Box 0946, University of Michigan Hospitals, 1500 E. Medical Center Drive, Ann Arbor, Ml 48109-0946.

Received December 2, 1998; revision received February 25, 1999; accepted February 25, 1999.

\section{Evaluation of Cancer Information on the Internet}

\author{
J. Sybil Biermann, M.D. ${ }^{1,2}$ \\ Gregory J. Golladay, M.D. ${ }^{1}$ \\ Mary Lou V. H. Greenfield, M.P.H., M.s. ${ }^{4}$ \\ Laurence H. Baker, D.0. ${ }^{2,3}$
}

\author{
${ }^{1}$ Section of Orthopaedic Surgery, Department of Surgery, University of Michigan Medical School, \\ Ann Arbor, Michigan. \\ ${ }^{2}$ University of Michigan Comprehensive Cancer Center, Ann Arbor, Michigan. \\ ${ }^{3}$ Division of Hematology and Oncology, Department of Medicine, University of Michigan Medical \\ School, Ann Arbor, Michigan. \\ ${ }^{4}$ Department of Anesthesia, University of Michigan Medical School, Ann Arbor, Michigan.
}

$\mathbf{T}$ he Internet is a massively expanding body of information, with an estimated 320 million Web pages available. ${ }^{1}$ In 1997 an estimated 24 million North Americans used the Internet, ${ }^{2}$ and Internet use has been estimated to double each year. ${ }^{3}$ Even prior to the advent of the Internet as a source of medical information, patients have become more informed regarding their care, ${ }^{4}$ seeking increased amounts of information regarding their diagnoses and primarily wanting more information regarding their treatment options. In the past, these patients would rely heavily on health professionals for this information, through conversations or from pamphlets, videos, or books available to physicians for office distribution. Some resourceful patients may have ventured into medical libraries and some may have navigated through Index Medicus. Even the accessibility of MEDLINE searches in libraries and public institutions provided patients chiefly with peer-reviewed medical articles.

We are living in a time of exponential expansion in accessibility to medical information. Data that previously would have required hours of research in a medical library now can be found easily by anyone with access to the Internet. This has enhanced the medical professional's ability to gain extensive knowledge of research findings from many different medical specialties. However, medical professionals are not the only ones searching the Internet for such information. Our patients have the same capability that we have to research a medical topic thoroughly via the Internet. However, of concern is the quality of this newly gained knowledge. The free flow of information on the Internet permits anyone with good computer skills and a modem to establish a Web site with whatever information they wish to share. In this respect, the Internet becomes the great equalizer: experts, specialists, authorities, professionals, alternative therapy promoters, interested lay people, charlatans, and hucksters all may set up sites containing information regarding specific topics of interest.

As physicians, we are concerned whether medical information 
TABLE 1

Yield of Sites by Search Engine with Four Spellings of Search Topic

\begin{tabular}{lllll}
\hline $\begin{array}{l}\text { Search } \\
\text { engine }\end{array}$ & $\begin{array}{l}\text { Spelling } \mathbf{1} \\
\text { Ewing's } \\
\text { sarcoma }\end{array}$ & $\begin{array}{l}\text { Spelling 2 } \\
\text { Ewing's } \\
\text { Sarcoma }\end{array}$ & $\begin{array}{l}\text { Spelling 3 } \\
\text { Ewings } \\
\text { sarcoma }\end{array}$ & $\begin{array}{l}\text { Spelling 4 } \\
\text { Ewings } \\
\text { Sarcoma }\end{array}$ \\
\hline Excite & 27013 & 27013 & 7254 & 7254 \\
Infoseek & 12403 & 679 & 11826 & 64 \\
Alta Vista & 1321 & 470 & 110 & 71 \\
Looksmart & 1321 & 470 & 110 & 71 \\
Hot Bot & 1240 & 570 & 84 & 55 \\
Webcrawler & 989 & 989 & 205 & 205 \\
Yahoo & 20662 & 20662 & 3848 & 3848 \\
\hline
\end{tabular}

found on the Internet by our patients is current and accurate. In the medical literature, the distinguishing characteristic of reputable and scientifically useful information is peer review; this process assures readers that publications have been submitted to review by acknowledged experts for their opinions and recommendations. ${ }^{5-7}$ The lay public for the most part is unaware of the peer review process as well as the degree of scrutiny to which published medical material has been subject. Although the form of peer review may differ from journal to journal, it generally is accepted that research studies submitted to peer review will be presented in such a way that potential users can assess observations, replicate the study experiments, and evaluate the authors' conclusions. ${ }^{8}$ Readers of peer-reviewed articles thus are reasonably assured that the data in such articles are scientifically valid and the conclusions drawn by the authors are sound. Do patients accessing the Internet for cancer information experience these same assurances regarding medical information found through their searches?

To evaluate the accuracy, ease, and variability of cancer information retrieval from a patient perspective, we performed a systematic study of cancer information on the Internet, categorizing and defining the information retrieved. Searching the broad topic of "cancer" or even one of the more common types of cancer such as cancer of the breast or prostate will yield unwieldy amounts of information. ${ }^{9}$ To narrow our search, we selected one medical topic to explore: Ewing sarcoma.

First, we used seven search engines available on the homepage of Netscape ${ }^{\mathrm{TM}}$, a popular Internet browser, ${ }^{10}$ to assess the number of Internet "addresses" or uniform/universal resource locators (URLs) given for the topic of Ewing sarcoma. We also tested different search engines using combinations of capitalization and punctuation of the term (Table 1) to simulate the variability that may occur when a person
INTERNET MEDICAL INFORMATION SEARCH

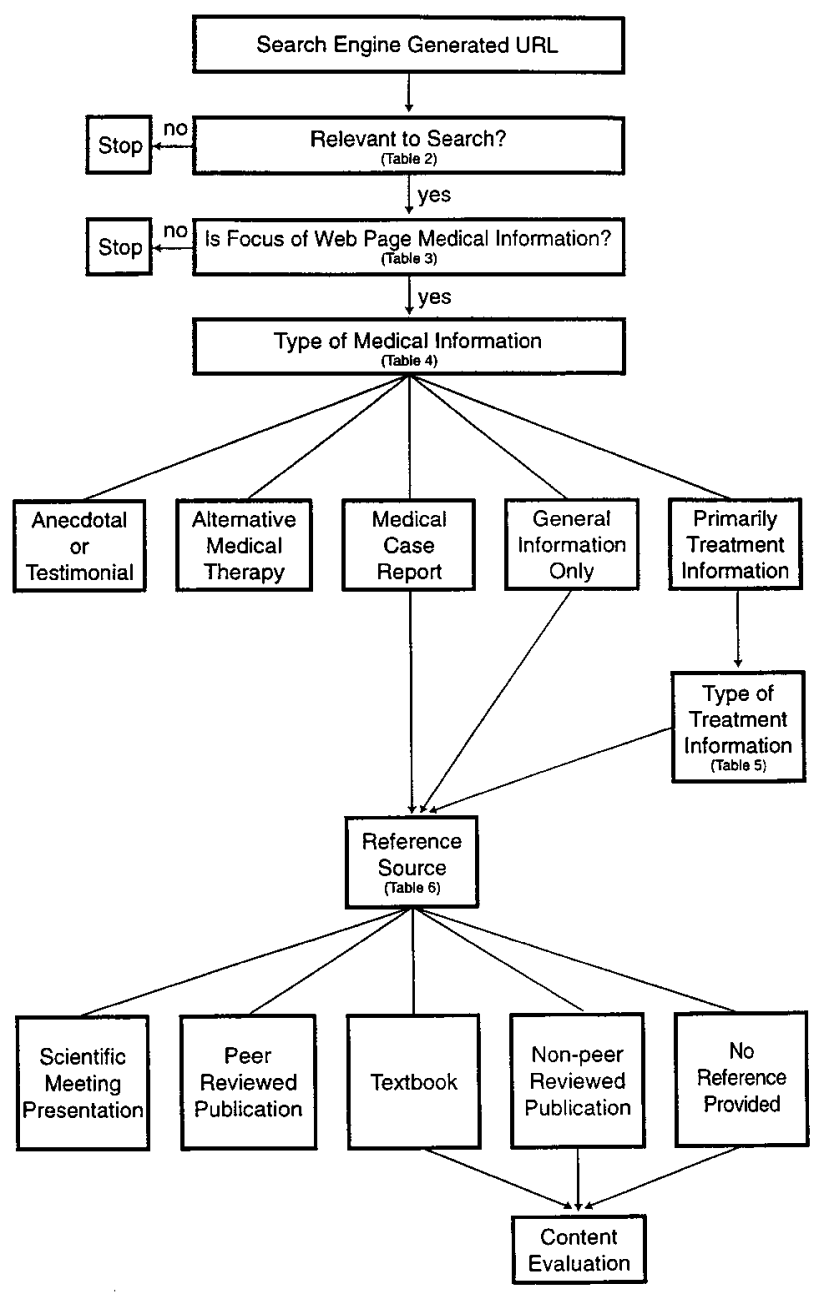

FIGURE 1. Summary of the flow of information using the guide developed by the authors to evaluate medical-related Web pages. URL: universal resource locator.

accesses this information. We used the more common "Ewing's" /"Ewings" to illustrate the point. To simulate the experience of a user with limited familiarity of the Internet, we did not use more sophisticated searching mechanisms (e.g., Boolean operators, which are available with some search engines).

Second, we developed a rating system to standardize an instrument we could use to abstract medical information (Fig. 1). Specifically, we devised this instrument to evaluate each Internet Web page for its relevance to the search topic, whether the site contained medical information, whether the information was anecdotal, and whether the information was peer reviewed. Furthermore, we evaluated the frequency of agreement and interobserver reliability between the two observers (J.S.B. and G.J.G.). Each observer eval- 
uated separately the first 25 consecutive sites listed using the Yahoo search engine during the same 24hour period. Twenty-four of the 25 sites were evaluable. The observers demonstrated perfect agreement (24 of 24) for classifying the main topics of each site, high agreement for the focus of each article (21 of 24), high agreement for the treatment content of the sites (21 of 24), and good agreement (18 of 24) for the source of the posting of the site. Kappa statistics were able to calculate for classification of site, medical information, and Internet sources for the two observers. ${ }^{11}$ All indicated high agreement when adjusted for the role of chance. Classifying medical information resulted in a kappa statistic equal to 0.74 (95\% confidence interval $[95 \% \mathrm{CI}], 0.5,0.98)$ and classifying posting sources resulted in a kappa statistic equal to 0.59 (95\% CI, 0.31, 0.87). (Kappas were unable to be obtained for all variables because the lack of data in some cells resulted in asymmetrical row and column distributions.)

Third, we selected four of the most commonly used search engines available from the Netscape home page. We used four rather than the initial seven search engines to generate a more manageable number of Web pages. Each of the two observers then undertook searches of "Ewing's Sarcoma," using two different search engines, during a 4 -week period. Observer 1 (J.S.B.) searched using Infoseek and Lycos; Observer 2 (G.J.G.) searched using Yahoo and Webcrawler. The first 100 postings for each search engine were analyzed using the rating system. This resulted in the analysis of 400 URLs.

The interconnecting, linked structure of the Internet can make it difficult to determine where one source of information ends and another begins. To standardize the evaluation of the retrieved material, we agreed that each evaluation would be conducted on the basis of the initial appearing page, and that hyperlinks would not be followed to other parts of the Web site, domain, or Internet. We made an exception if the initial page was a table of contents with "Ewing's Sarcoma" listed, allowing one hyperlink to the page listed. We evaluated each page (including scrolling), that appeared after making the hypertext link from the search engine results.

Figure 1 summarizes the flow of information using the guide we developed for evaluating medical Web pages. We first classified the sites according to their relevance to the topic of inquiry. Some Web pages were completely unrelated to Ewing's sarcoma and had to do with the use of the word "Ewing" in another context (for example, an individual with the surname "Ewing"). Other Web pages mentioned Ewing sarcoma, but in such a way that they would be irrelevant to the reader searching for information regarding the medical diagnosis. (For example, Ewing sarcoma appeared in the publication list of a molecular biologist who used Ewing cell lines in one experiment.) Web pages were rated "peripherally related" if they provided some information regarding Ewing sarcoma but mainly were about another subject (for example, causes of bone pain in children). Other pages were rated as "relevant" if information included Ewing sarcoma as a significant subset of a group (e.g., "sarcomas" or "bone cancers"). Finally, articles whose main topics were about Ewing sarcoma were classified as the "main point."

For those pages considered to have relevance to Ewing sarcoma, whether peripherally related, dealing with the disease as part of a larger group, or with Ewing sarcoma as the main point, we next evaluated the type of information they contained. We separated Web pages into those that primarily were human interest stories (for example, correspondence from discussion groups that occasionally appeared as a product of the search engines), those that primarily were link pages to other sites, and those pages that actually contained medical information.

The pages that contained medical information then were classified by the type of information: 1) anecdotal or testimonial, 2) primarily concerned with alternative medical therapy, 3) medical case reports, 4) general descriptions or diagnostic information only, or 5) primarily containing treatment information.

Because we were interested in the type of treatment information available, we evaluated the subgroup of pages that had specific information regarding treatment. Specifically, we determined whether the treatment was from 1) national or cooperative group clinical trials, 2) institutional clinical trials, 3) both national and institutional trials, 4) institutional reports, or 5) if the treatment discussed was not specific to Ewing sarcoma.

For all Web pages that contained medical information, we rated the information according to its peer review status: 1) posting without reference to publication or presentation, 2) posting from a nonpeer-reviewed journal or publication, 3) posting from a printed textbook, 4) posting with reference to a medical or scientific meeting presentation, or 5) posting from a peer-reviewed source, including peer-reviewed publications, consensus statements, and national or institutional trials.

Finally, all material that was evaluated as medical information but not peer reviewed was read carefully by two of the investigators (J.S.B and L.H.B) to discern gross factual inaccuracies. We used the textbook by DeVita et al. ${ }^{12}$ as a standard for comparison. We con- 
TABLE 2

Results of 100 URLs from Each of Four Search Engines Using Search Term "Ewing's Sarcoma"

URLs

Duplications

Foreign language or inaccessible site

Web page content not relevant to search

Web page topic peripherally related to search term

General topic of web page includes search term

Main topic of web page is same as search term

Total

URL: universal resource locator

TABLE 3

Summary of Web Pages with Focus Relevant to Search Term "Ewing's Sarcoma" (n = 215)

\begin{tabular}{ll}
\hline Context of Web pages & \\
\hline Human interest story & 7 \\
Link page & 38 \\
Medical information & 170 \\
\hline
\end{tabular}

sidered inaccurate only those statements that were notably divergent from currently accepted information on the topic and material presented in the text.

We found considerable variability among the numbers of URLs retrieved based on various spellings and the use of different search engines (Table 1). Retrieved URLs from a search on "Ewing's Sarcoma" varied from 55 (HotBot, searching "Ewings Sarcoma”) to 27,013 (Excite). Although some search engines gave equal numbers of URLs independent of capitalization (Excite, Webcrawler, and Yahoo), others did not (Looksmart, Infoseek, HotBot, and Alta Vista). Furthermore, in some search engines the presence or absence of the apostrophe affected search results as well.

Of the 400 URLs evaluated (100 from each of 4 search engines), 29 were duplicated on at least 2 of the search engines. Thus, 371 unique evaluable URLs were included in this study (Table 2). To verify the reliability of our rating system, we used a random numbers table to select 25 sites from the search list to be reevaluated by each observer. The kappa statistic for interobserver reliability was 0.65 (95\% CI, 0.38, 0.92), indicating good agreement between the observers for classifying pages by important information related to Ewing sarcoma. Intraobserver reliability also was good with a kappa statistic for Observer 1 of 0.75 (95\% CI, 0.55 , 0.95) and a kappa statistic for Observer 2 of 0.91 (95\% CI, 0.74-1.0).

Further evaluation demonstrated that the major-
TABLE 4

Description of Medical Information on Web Pages for Search Term "Ewing's Sarcoma" (n = 170)

\begin{tabular}{ll}
\hline Types of medical information & \\
\hline Diagnostic or general information only & 118 \\
Treatment information & 44 \\
Anecdotal or testimonial & 4 \\
Medical case report or series & 3 \\
Alternative medicine & 0 \\
\hline
\end{tabular}

TABLE 5

Type of Treatment Information for Web Pages with Search Term "Ewing's Sarcoma" ( $\mathrm{n}=44)$

Sources

National or cooperative group trials

Institutional trials

Both national/cooperative group and institutional trials

Institutional report

Treatment not specific to topic of search

Treatment not specific to topic of search

TABLE 6

Reference Sources for Medical Information on Web Pages for Search Term "Ewing's Sarcoma" ( $=$ 165)

\begin{tabular}{ll}
\hline Sources & \\
\hline Peer-reviewed publications & 95 \\
No reference source listed & 57 \\
Textbook & 5 \\
Presentation at scientific meeting & 5 \\
Nonpeer-reviewed publications & 3 \\
\hline
\end{tabular}

ity (215 of 371) of the URLs led to Web pages that contained medical information; 7 pages were human interest stories containing no medical information and 38 pages predominantly were link pages with little or no medical information (Table 3). We further evaluated those pages with medical information (Table 4) and found that the majority contained general information related to the diagnosis or treatment of Ewing sarcoma and 44 pages contained information regarding specific treatments. For those pages addressing specific types of treatment (Table 5), 15 of 44 pages concerned treatment dealing with national or cooperative group trials for Ewing sarcoma. Approximately $30 \%$ of the pages (13 of 44 ) dealt with treatments that were not specific to Ewing sarcoma (for example, bone marrow transplant for solid tumors of childhood).

Of the 170 pages containing medical information, 165 were evaluable for the reference source of the information (Table 6). Approximately 35\% (57 of 165) of the Web pages contained no reference to peer review. Approximately 58\% (95 of 165) contained infor- 
mation that was peer reviewed. Many of the Web pages containing peer-reviewed material had copied the PDQ information from the National Cancer Institute.

Finally, we combined all sources of medical information determined not to be peer reviewed (i.e., nonpeer-reviewed sources, textbook sources, or no sources listed) and evaluated these for accuracy of content ( 65 of 165). We were able to find 4 cases (4 of $70 ; 6 \%)$ of clearly erroneous information. The Encyclopaedia Britannica's Web page stated that "Ewing's tumour is particularly destructive, metastasizes (seeds itself elsewhere in the body) early, and has a mortality rate of about $95 \%$ even with radical therapy." On a different page, retrieved independently, it went on to say that "sarcomas are generally divided into bone and soft-tissue tumors, the latter being much less common" (http:/www.eb.com/cgi-bin/g?keywords =Ewing\%27s\%20sarcoma\%20\%28path\%2e\%29). And, lastly, a third page cited a survival rate for Ewing sarcoma as $85 \%$ (http://www.worldmall.com/erf/ lectures/bones.htm) (too high). We also found information so outdated as to be erroneous: "Always get some fresh tissue to be set in glutaraldehyde for EM studies" (http://gasbone.herston.uq.edu.au/ ortho/ regsum/genorth/09TUMOR/Ewings.html). (The use of immunohistochemistry, cytogenetics, and, in some cases polymerase chain reaction, has replaced the use of electron microscopy in the diagnosis of Ewing sarcoma.)

We also found a number of mildly misleading statements such as "This tumor is frequently fatal" (http://familyinternet.com/mhc/top/001302.htm). Although this statement is not patently false, when interpreted in the strictest sense, it still has significant potential to be misleading.

With the advent of the Internet, not only can anyone search for information, but nearly anyone with a computer, modem, and some programming skills can disseminate information widely and sometimes indiscriminately. Search engines now access Web pages from reputable sources such as the National Cancer Institute or the American Cancer Society sideby-side with other sites that include only anecdotal experience or testimonials from discussion groups. Although peer review remains the mechanism whereby the widespread dissemination of unchecked medical information is minimized in printed material, no such restraint necessarily is present on the Internet. There are 1.7 cases of Ewing sarcoma per million in the white population, ${ }^{12}$ or approximately 250 new cases diagnosed annually in the U.S.; nevertheless, when one searches the Internet for postings on this disease, thousands of records may be retrieved. A sig- nificant portion of the material reviewed on the Internet in our study was not peer reviewed, and some of it was erroneous. Table 7 lists Web page references found for the search term "Ewing's Sarcoma."

Inclusion of a Web page in a searchable index depends not on quality standards developed for the evaluation of medical information but on "net appeal," which refers to the level of innovation used on the page such as graphics, sound, and color. ${ }^{13}$ A number of purported health information rating systems have been developed for Internet use, but they are incompletely developed instruments and it is unclear whether they actually are helpful. ${ }^{14}$

The factually incorrect and misleading Web pages found in this study are particularly concerning. It is not intuitively obvious that a sophisticated instrument such as the computer may yield inaccurate or false information. Although an inaccuracy rate of $6 \%$ may not appear high, in our study it is the quality rather than the quantity of misinformation that is at issue. For example, Web pages reported survival rates as low as $5 \%$ or as high as $85 \%$. The majority of experts anticipate a survival rate of $70-75 \% .^{12,15}$ The parents of a child diagnosed with Ewing sarcoma may be devastated by a finding on the Internet of a $95 \%$ mortality rate, and even be driven to consider refusing therapy if they are convinced that conventional medial science (even "radical" therapy) yields such a dismal prognosis. Alternatively, they may believe that an organization that lists an $85 \%$ cure rate may provide better therapy than one that posts a cure rate more in line with the peer-reviewed published trials. Although inaccurate or misleading statements may represent a small minority of the information available, the devastating effect these postings would have on vulnerable patients is incalculable. Even subtle inaccuracies may create a wedge between physician and patient. ${ }^{16}$ For example, a patient who learns from the Internet that bone sarcomas are more common than soft tissue sarcomas may be startled to hear his physician say otherwise, and such contradictions have the potential to create doubt and distrust in the patient's mind.

Furthermore, patients may spend hours in fruitless, frustrating searches, finding a few helpful sites but sifting through many dead ends. Attempts to access medical information using search engines may be very cumbersome and time-consuming. We found that nearly $50 \%$ of the URLs appearing in the top 100 listings of search engines were either inaccessible, not in English, or unrelated to the medical topic searched. That there were only 29 duplicates found when 4 different search engines were examined in our study suggests that there may be considerable variability depending on the search engine used. 
TABLE 7

Web Page References for Search Term "Ewing's Sarcoma" ( $n=400)$

URL

ftp://ftp.csn.net/COGS/Hydrology/Spatial/comtech

ftp://theta.iis.u-tokyo.ac.jp/publ/X/R5contrib/GlF

http://192.50.14.33:8083/0/CNET/All_files/100759=@=gopher:ganl.ncc.go.jp:70=0

http://adwww.fnal.gov/ntf/neutrons_against_cancer/neutrons_against_cancer.html http://adwww.fnal.gov/ntf/ntf_linical.html

http://animal.fnal.gov/ntf/neutrons_against_cancer/neutrons_against_cancer.html http://asterix.bio.sunysb.edu/Viola.html

http://biomed.nus.sg/Cancer/index.html

http://biomed.nus.sg/Cancer/PhyPat.html

http://biomed.nus.sg/MEDNEWS/may95/hicn8211_4.html

http://biomednet.com/hmsbeagle/

http://bitmed.med.uchile.cl/menuingl.html

http://bitmed.med.uchile.cl/menuingl.html

http://cancer.med.upenn.edu/disease/ewing/

http://cancer.med.upenn.edu/pdq_html/2/engl/200021.html

http://cancer.med.upenn.edu/psychosocial/psst/mar95.html

http://cancerguide.org/rare_cancer.html

http://cancernet.nci.nih.gov/clinpdq/pif.html

http://cancernet.nci.nih.gov/clinpdq/soa.html

http://cancernet.nci.nih.gov/jnci/iss8805/88-270.html

http://cancernet.nci.nih.gov/jnci/issue12/87-12toc.html

http://cancernet.nci.nih.gov/jnci/issue12/87-12toc.html

http://cancernet.nci.nih.gov/jnci/issue22/22iti.html

http://cancernet.nci.nih.gov/jnci/issue22/86-1702.html

http://cancernet.nci.nih.gov/jnci/issue22/86-1702.html

http://cancernet.nci.nih.gov/jnci/issue5/87-5toc.html

http://cancernet.nci.nih.gov/pedpage/FAQ.html

http://cancernet.nci.nih.gov/pedpage/MolOncol.html

http://cancernet.nci.nih.gov/pedpage/SolidTum.html

http://cancernet.nci.nih.gov/pedpage/SolidTum.html

http://cancernet.nci.nih.gov/prot/docs/pro08322.html

http://cancernet.nci.nih.gov/prot/docs/pro09638.html

http://cancernet.nci.nih.gov/prot/docs/pro10767.html

http://cancernet.nci.nih.gov/prot/docs/pro10908.html

http://cancernet.nci.nih.gov/prot/docs/prol1022.html

http://cancernet.nci.nih.gov/prot/docs/prol1178.html

http://cancernet.nci.nih.gov/prot/menu/dx00021.htm

http://cancernet.nci.nih.gov/prot/menu/dx00021.html

http://cancernet.nci.nih.gov/prot/menu/dx00047.html

http://cancernet.nci.nih.gov/prot/menu/dx00719.html

http://cancernet.nci.nih.gov/prot/menu/dx00963.html

http://cancernet.nci.nih.gov/prot/menu/dx01121.html

http://cbil.humgen.upenn.edu/ cbell/paper.html

http://count51.med.harvard.edu/AANLIB/cases/case33/mrl/000.html

http://count51.med.harvard.edu/AANLIB/cases/case33/mr1/017.html

http://count51.med.harvard.edu/AANLIB/cases/case33/mr2/017.html

http://count51.med.harvard.edu/AANLIB/home.html

http://cpmcnet.columbia.edu/dept/cerebro/Stein.html

http://cwis.unimelb.edu.au/research.report/current/531.html

http://cwis.unimelb.edu.au/research/research.report/1993/Medicine/571.html

http://detnews.com/menu/stories/40518.html

http://edcenter.med.cornell.edu/CUMC_PathNotes/Skeletal/Bone_07.html

http://espn.sportszone.com/nba/news/980102/00517903.html

http://espnet.sportszone.com/nba/

http://espnet.sportszone.com/nba/clubhouses/nyk.html

http://familyinternet.com/mhc/top/001302.htm

http://fonop.cineca.it/Activities/Protocolli/SE.htm

http://fonop.cineca.it/Activities/Protocolli/SE.htm

http://gait.aidi.udel.edu/res695/homepage/pd_ortho/educate/clincase/eposteo.html
URL

http://gamma.wustl.edu/bs001te143.html

http://gamma.wustl.edu/bs001tel43.html

http://gasbone.herston.uq.edu.au/ 0rtho/regsum/genorth/09TUMOR/Ewings.html

http://health.ucsd.edu/ntrials/970628.htm

http://home.coqui.net/titolugo/database.htm

http://home.coqui.net/titolugo/indice.htm

http://home.coqui.net/titolugo/PSU09.html

http://Home.InfoRamp.Net/ eridani/

http://home.ipoline.com/ guoli/med/dicts.htm

http://home.pacbell.net/ewing/

http://home.pacbell.net/ewing/rneres.html

http://imsdd.meb.uni-bonn.de/cancernet/102891.html

http://imsdd.meb.uni-bonn.de/cancernet/200021.html

http://imsdd.meb.uni.bonn.de/Cancernet/100759.html

http://imsdd.meb.uni.bonn.de/cancernet/patients.toc.html

http://imsdd.meb.uni.bonn.de/cancernet/pdqphy.menu.html

http://journals.wiley.com/cancer/oldtocs/78.4.html

http://journals.wiley.com/cancer/tocs/739fxtoc.html

http://journals.wiley.com/cancer/tocs/78-4.html

http://korbl.sote.hu/KKK/DESCRIPT/0004/0004065E.HTM

http://korbl.sote.hu/KKK/DESCRIPT/0004/0004186E.HTM

http://labmed.ucsf.edu/AP/docs/path103_lec/lec_73bone.html

http://meds.ss10.meds.queensu.ca/medicine/musculo/37.htm

http://members.tripod.com/ joep/brandyl.html

http://neuron.chem.psu.edu/

http://nisc8a.upenn.edu/disease/ped_ewing/

http://NISC8A.upenn.edu/pdq/200021.html

http://nisc8a.upenn.edu/pdq_html/2/engl/200021.html

http://NISC8A.upenn.edu/pdq_html/2/engl/200021.more.html http://noah.cuny.edu/cancer/nci/cancernet/100759.html http://noah.cuny.edu/cancer/nci/cancernet/physician.html http://oncolink.upenn.edu/cancernet/95/nov/711560.html http://oncolink.upenn.edu/cancernet/95/sept/709560.html http://oncolink.upenn.edu/cancernet/96/june/706440.htm http://oncolink.upenn.edu/cancernet/96/mar/703455.html http://oncolink.upenn.edu/cancernet/96/sept/709301.html http://oncolink.upenn.edu/disease/ewing/ http://oncolink.upenn.edu/disease/ewing/ http://oncolink.upenn.edu/disease/ewing/index.html http://oncolink.upenn.edu/forms/listserv.html http://oncolink.upenn.edu/pdq_html/1/engl/ http://oncolink.upenn.edu/specialty/gyn_onc/endomet/ http://orthoweb.unicall.be/06/176.html http://pages.prodigy.com/TN/theatre/horizons.html http://path.upmc.edu/cases/case103/dx.html http://path.upmc.edu/cases/case103/dx.html http://path.upmc.edu/people/faculty/dickman.html http://path.upmc.edu/showcase/quarterly/1995-lqtr.html http://pharminfo.com/pin_hp.html http://phobos.cc.ankara.edu.tr/ tnd/biblioin.htm http://pilot.msu.edu/user/chaikenj/contrib.html http://pweb.netcom.com/ chris-d/cancer.htm http://rpisunl.mda.uth.tmc.edu/pediatric/index.html http://ruly70.medfac.leidenuniv.nl/pub95.html http://sciweb.com/apoptosis/index.html http://sdm.uchc.edu/ProjectD/Roadmap.html http://sdm.uchc.edu/ProjectD/Roadmap.html http://seidata.com/ marriage/rcancer.html http://telescan.nki.nl/start/chapt-01/table.html 
TABLE 7 (continued)

URL

http://telpath2.med.utah.edu/WebPath/BONEHTML/BONEIDX.html http://vega.rz.uni-duesseldorf.de/ kmonser/Final_Programm_3.html http://worldmall.com/erf/lectures.htm

http://www-lj.eb.com:82/index.htcl/aDB/index_alpha/thisRow/69373/ http://www-md.fsl.noaa.gov/ romberg/formatters/textproducts.html http://www-md.fsl.noaa.gov/ romberg/rombergHome.html http://www-medlib.med.utah.edu/WebPath/LABS/BONELAB/BONEA02.html http://www-medlib.med.utah.edu/WebPath/TUTORIAL/HERPES/HERPES.html http://www-radonc.stanford.edu/donaldson.html

http://www.aacr.org/a091597.htm

http://www.aaos.org/wordhtml/anmeet89/scipro/ppr042.htm http://www.aaos.org/wordhtml/anmeet89/scipro/ppr042.html http://www.aaos.org/wordhtml/anmeet90/scipro/ppr393.htm http://www.aaos.org/wordhtml/anmeet97/sciprog/175.htm http://www.aaos.org/wordhtml/anmeet97/sciprog/176.htm http://www.aaos.org/wordhtml/anmeet97/sciprog/177.htm http://www.aaos.org/wordhtml/scil3.97.htm http://www.aap.org/bpi/Radiology.html

http://www.adventure.com/encyclopedia/sports/patewing.html http://www.allenewing.com/

http://www.alternatives.com/libs/hecancer.htm

http://www.arc.com/database/Cancernet/english/patient/index.html http://www.arc.com/database/Cancernet/english/patient/index.html http://www.arc.com/database/Cancernet/english/physician/index.html http://www.at-home.com/get_doc/1928179/3984 http://www.at-home.com/get_doc/1928179/4005 http://www.belgianorthoweb.be/links/topics.html http://www.biotech.ist.unige.it/cldb/cl2883.html http://www.biotech.ist.unige.it/cldb/tumors.html http://www.bovision.se/bin/cgimaklarsida.exe?311 http://www.calverley.co.uk/dark.html

http://www.cancer-info.com/cantypes.htm

http://www.cancer-info.com/phonenos.htm http://www.cancer.org/statistics/97cff/97childr.html http://www.cancerguide.org/rare_cancer.html http://www.cas.usf.edu/lis/lis2002/summer96/chhabra.html http://www.cbil.upenn.edu/ cbell/paper.html http://www.cc.emory.edu/PEDS/HEMONC/clinprog.htm http://www.ccc.columbia.edu/protocol/peds.html http://www.centroatl.pt/wedding/imagens/flor.gif http://www.charm.net/ kkdk/ http://www.charm.net/ kkdk/sarcoma_html/ http://www.chem.umu.se/divisions/env/bvb.html http://www.chem.umu.se/divisions/env/bvb.html http://www.cilnews.unige.it/Cil.News/ospedale/HTML/oncoines.htm http://www.cityscape.co.uk/users/ad88/paeds/pedonca.html http://www.cnnsi.com/basketball/nba/teams/knicks/ http://www.columbia.net/phys/hamilton.html http://www.columbia.net/phys/lenarsky.html http://www.columbia.net/phys/lenarsky.html http://www.coredcs.com/ lsrsjaco/basketball/ http://www.cshl.org/books/mol_gen_cancer.html http://www.cshl.org/books/symp-59.htm http://www.dreamcatcher.com/dako/gallery/e/ewings.html http://www.eb.com/cgi-bin/g?keywords=Ewing\%27s\%20sarcoma http://www.emkf.org/ http://www.emkf.org/entrepreneurs/index.html http://www.emkf.org/grants/index.html http://www.emkf.org/mr.k/index.html http://www.emkf.org/yd/index.html
URL

http://www.entreworld.org/

http://www.ewingfoley.com/

http://www.ewingtwp.com/

http://www.fhcrc.org/ clinical/

http://www.freep.com/sports/pistons/qpistonl71.htm

http://www.graylab.ac.uk/cancernet/102891.html

http://www.graylab.ac.uk/cancernet/pdqphy.menu.html

http://www.graylab.ac.uk/cancernet/pdqpt.menu.html

http://www.graylab.ac.uk/cancernet/spanish/100759.html

http://www.graylab.ac.uk/white/uv.html

http://www.gretmar.com/cancernet/102891.txt

http://www.gretmar.com/webdoctor/OncologyBone.html

http://www.healthanswers.com/database/ami/converted/001302.html

http://www.healthatoz.com/categories/MESCPEIO.htm

http://www.healthwise.org/toplist.htm

http://www.house.gov/ewing/

http://www.icnet.uk/lis/ipub/scirep95/089a.html

http://www.icondata.com/health/pedbase/files/LIMP.HTM

http://www.icondata.com/health/pedbase/files/OSTEOSAR.HTM

http://www.iit.edu/ Access/nasa_k12/03sci.htm

http://www.inforamp.net/ eridani/

http://www.inforamp.net/ eridani/ewings.html

http://www.inforamp.net/ eridani/index.html

http://www.inform.umd.edu/CompRes/NetInfo/Newsletters/HealthInfoCom/ v8n21.health

http://www.innercite.com/ bchance/KSharp.shtml

http://www.intap.net/ dsrct/biblio.htm

http://www.isc.tamu.edu/PICS/FY94-report/nodel.html

http://www.jcojournal.org/abs14_10/13xx0013.htm

http://www.jcojournal.org/abs15_7/v15n7p2611.html

http://www.jcojournal.org/previous/toc15_2.html

http://www.jcojournal.org/previous/toc15_7.html

http://www.jcojournal.org/previous/toc15_7.html

http://www.jim-mullins.com/

http://www.kcchos.onnet.co.kr/article.html

http://www.kcchos.onnet.co.kr/site_1.html

http://www.kidswithcancer.com/main/re_bone.html

http://www.labvision.com/1209.htm

http://www.labvision.com/1209.html

http://www.largnet.uwo.ca/info/keywords.html

http://www.luxury-realestate.com/firms/ewing.htm

http://www.majors.com/htmltocs/piz0353z.html

http://www.mallinckrodt.nl/nucmed/noframes/nuclear/paediatr/hahn.htm

http://www.mcacademy.org/s_c.htm

http://www.mdacc.tmc.edu/ andnet/paula.html

http://www.mdacc.tmc.edu/ andnet/paula.html

http://www.meb.uni-bonn.de/cancernet/100021.html

http://www.meb.uni-bonn.de/cancernet/cancernet_documents.html

http://www.meb.uni-bonn.de/cancernet/physicians.toc.html

http://www.meb.uni.bonn.de/cancernet/spanish/100759.html

http://www.med.harvard.edu/AANLIB/cases/case33/case.html

http://www.med.harvard.edu/AANLIB/home.html

http://www.med.harvard.edu/publications/Focus/complete_texts/

Dec16_1994_complete.html

http://www.med.harvard.edu/publications/Focus/Dec16_1994/calendar.html http://www.med.jhu.edu/cancerctr/peds/cantype.htm

http://www.medhelp.org/perl6/general/wwwboard.html

http://www.medinfo.org/nci/cancernet/2/200021.html

http://www.medinfo.org/nci/cancernet/pdqphy.html

http://www.medinfo.org/nci/cancernet/pdqpt.html 
TABLE 7 (continued)

URL

http://www.medinfo.ufl.edu/other/ortho/

http://www.medlib.iupui.edu/bcr/

http://www.medlib.iupui.edu/bcr/CurrentResearch.html

http://www.medlib.iupui.edu/bcr/CV.Rougraff.htm

http://www.medlib.iupui.edu/bcr/LocalControlPedSarcomas.htm http://www.medlib.iupui.edu/bcr/LocalControlPedSarcomas.htm http://www.medlib.iupui.edu/bcr/newsletter3.html

http://www.medmark.org/onco/onco.html http://www.medmedia.com/l8/359.html

http://www.medmedia.com/06/126.html

http://www.medmedia.com/06/127.htm

http://www.medmedia.com/06/136.htm

http://www.medmedia.com/orthoo/2502.htm

http://www.meds.com/archive/mol.cancer/1996/msg00308.html

http://www.meds.com/archive/mol.cancer/1996/msg00316.html

http://www.meds.com/archive/mol.cancer/1996/msg00317.html

http://www.meds.com/archive/mol.cancer/1996/msg00318.html

http://www.meds.com/glossary.html

http://www.meds.com/mol/archive/mol-cancer/msg01184.html http://www.meds.com/mol/archive/mol.cancer/msg00479.html http://www.meds.com/mol/archive/mol.cancer/msg00480.html http://www.meds.com/mol/archive/mol.cancer/msg00481.html http://www.merck.com/!!tsfK310KetsfK310Ke/pubs/mmanual/html/nnjmjlig.htm http://www.mic.ki.se/Diseases/c4.html

http://www.microhosting.com/ molocure/

http://www.mosbychl.com/mhc/index/diseidxe.htm

http://www.nando.net/AT/ATmain.html

http://www.nando.net/newsroom/sports/bkb/1995/nba/nyk/feat/nyk.html

http://www.nba.com/boxscores/101596/houston_newyork.html

http://www.nba.com/games9798/971109/nyksac/recap.html

http://www.nba.com/knicks/inside.htm

http://www.ncc.go.jp/CNET/cnetl.html

http://www.nccf.org/nccf/protocol/7942.htm

http://www.nccf.org/nccf/protocol/b9511.htm

http://www.nccf.org/nccf/whatsnew/dlemons.htm

http://www.ncl.ac.uk/ nchwww/guides/clinks1.htm

http://www.ncl.ac.uk/ nchwww/guides/clinks4e.htm

http://www.ncl.ac.uk/ nchwww/guides/clinks5e.htm http://www.ncl.ac.uk/ nchwww/guides/clinks7.htm

http://www.ncl.ac.uk/ nchwww/guides/glos_ndx.htm

http://www.ncl.ac.uk/ nchwww/guides/guide2.htm

http://www.ncl.ac.uk/ nchwww/guides/guide2b.htm

http://www.ncl.ac.uk/ nchwww/guides/guide2b.html

http://www.ncl.ac.uk/ nchwww/guides/guide2e.htm

http://www.ncl.ac.uk/ nchwww/neccr.html

http://www.ncl.ac.uk/ nchwww/projlst.html

http://www.ncl.ac.uk/ nsjc5/eicess.htm

http://www.ncl.ac.uk/ nsjc5/eicess.htm

http://www.nejm.org/publicM/1996/0335/0017/1326a/1.htm

http://www.netrail.net/ dginn/rcancer.html

http://www.nhgri.nih.gov/Policy_and_public_affairs/Communications/

Press_releases/chromosome-22.htm

http://www.noah.cuny.edu/cancer/cancer.html

http://www.noah.cuny.edu/cancer/cantypes.html

http://www.noah.cuny.edu/cancer/nci/cancernet/200021.html

http://www.noah.cuny.edu/cancer/nci/cancernet/patient.html

http://www.noah.cuny.edu/cancer/nci/cancernet/physician.html

http://www.nt.sympatico.ca/Contents/Health/REV_HTML/S21388.html

http://www.nursingcenter.com/continuing/ce/cesonline.cfm
URL

http://www.ohsu.edu/cliniweb/C4/C4.557.450.565.575.650.html

http://www.ohsu.edu/cliniweb/C5/C5.116.html

http://www.ohsu.edu/cliniweb/C6/C6.240.476.html

http://www.ohsu.edu/cliniweb/C6/C6.405.748.html

http://www.ohsu.edu/cliniweb/intern/14.html

http://www.oncolink.com/disease/bonel/

http://www.oncolink.com/pdq_html/2/engl/200021.html

http://www.oncolink.upenn.edu/pdq/200021.html

http://www.oncolink.upenn.edu/pdq_html/1/engl/1000

http://www.oncolink.upenn.edu/pdq_html/1/engl/100021-4.html

http://www.oncolink.upenn.edu/pdq_html/cites/11/11789.html

http://www.oncoweb.com/

http://www.oncoweb.com/

http://www.ornl.gov/hgmis/publicat/hgn/v6n5/14chrom2.html

http://www.ornl.gov/TechResources/Human_Genome/publicat/hgn/v6n5/

14chrom2.html

http://www.pathfinder.com/living/latest/RB/1998Jan16/733.html

http://www.ped.h.u-tokyo.ac.jp/L74-96.html

http://www.ped.h.u-tokyo.ac.jp/L7Hayashi.html

http://www.ped.h.u-tokyo.ac.jp/L7Ida.html

http://www.priory.co.uk/journals/paeds/pedonca.htm

http://www.psrg.lcs.mit.edu/ bvelez/std-colls/med/med-542.htm

http://www.psrg.lcs.mit.edu/ bvelez/std-colls/med/med-542.html

http://www.quickwriter.com/

http://www.rad.washington.edu/Books/Approach/Lucent.html

http://www.radio.cbc.ca/radio/services/hotsheets/1995/04-April-1995/hotsheet.

Apr-04.html

http://www.ralphmoss.com/qcpers.html

http://www.rights.org/ deathnet/cancerNET.html

http://www.rush.edu/Med/cancer/fal95/challenge.html

http://www.salick.com/resource/sitee.html

http://www.salick.com/resource/sitee04.html

http://www.salick.com/resource/sites02.html

http://www.salick.com/resource/sites02.html

http://www.saul.com/

http://www.saul.com/address.html

http://www.saul.com/area.html

http://www.saul.com/berwyn/berwyn.html

http://www.saul.com/contents.html

http://www.saul.com/groups/env-grp.html

http://www.saul.com/harris/harris.html

http://www.saul.com/new.html

http://www.saul.com/princetn/princetn.html

http://www.saul.com/sources.html

http://www.saul.com/updates.html

http://www.saul.com/updates/est-ud.html

http://www.sbu.ac.uk/ dirt/museum/451-3211.html

http://www.sbu.ac.uk/ dirt/museum/p4-3281.html

http://www.sbu.ac.uk/ dirt/museum/p4-3281.html

http://www.sbu.ac.uk/ dirt/museum/pathindx.html

http://www.sonic.net/ jpat/getwell/tnr.html

http://www.southam.com/NewMedia/SI/kstory/kate5.html

http://www.spectraweb.ch/ mluethl/ewing.html

http://www.spectraweb.ch/ mlueth1/ewing.html

http://www.spectraweb.ch/ mlueth1/ewing.txt

http://www.spectraweb.ch/ mluethl/ewing.txt

http://www.sportingnews.com/nba/teams/knicks/

http://www.sportsline.com/index.html

http://www.sportsnote.com/nba/ 
http://www.sprinklers.com/

http://www.stepstn.com/nord/org_sum/89.htm

http://www.stepstn.com/nord/rdb_sum/765.htm

http://www.stjude.org/Medical/ewing.htm

http://www.stjude.org/toc.htm

http://www.stjude.org/toc.htm

http://www.subnet.com./ss273.htm

http://www.sunzine.net/business/didgeridoo/artbin/gobut.gif

http://www.swmed.edu/home_pages/facultystaff/may/OrthoSurg/TeachConf.html

http://www.thriveonline.com/@@4etMjwUAVGoPnI32/thrive/health/Library/ pedillsymp/pedillsymp613.html

http://www.thriveonline.com/@@BTcESAQAvFkzdASr/thrive/health/Library/CAD/ chronic/bone.html

http://www.thriveonline.com/@@Ddj@GwQAtlnOuvmi/thrive/health/Library/CAD/ abstract2189.html

http://www.thriveonline.com/@@0wUAywQAZFksPIar/thrive/health/Library/CAD/ abstract2189.html

http://www.thriveonline.com/@@RL5JyAUAV2p@6aa4/thrive/health/Library/ pedillsymp/pedillsymp613.html

http://www.thriveonline.com/@@saXqKAUAVmolJRzb/thrive/health/Library/CAD/ chronic/child.html

http://www.thriveonline.com/@@TG6FXgUAVmqc6U3M/thrive/health/Library/ $\mathrm{CAD} /$ chronic/bone.html

http://www.tica.org/vet8.htm

http://www.tirgan.com/actinomy.htm

http://www.tirgan.com/bone.htm http://www.trs-p.co.jp/service/dtp.html

http://www.unc.edu/ lbrooks2/ewing.html

http://www.universityorthopedics.com/uopropap.htm

http://www.unmc.edu/Pathology/molecular/bridge.html

http://www.unmc.edu/Pathology/molecular/molecyto.html

http://www.uq.net.au/MitcheltonHS/honour.html

http://www.urmc.rochester.edu/smd/derm/Derm_Page/scottRES.html

http://www.users.globalnet.co.uk/ ewing/chat.htm

http://www.users.globalnet.co.uk/ ewing/links.htm

http://www.users.globalnet.co.uk/ ewing/movie.htm

http://www.users.globalnet.co.uk/ ewing/news.htm

http://www.users.globalnet.co.uk/ ewing/problem.htm

http://www.users.globalnet.co.uk/ ewing/south.htm

http://www.users.globalnet.co.uk/ ewing/trivia.htm

http://www.users.med.cornell.edu/ spon/peds/specialt/faculty.htm

http://www.utoronto.ca/mrcpp/people/seth.htm

http://www.vtmednet.org/children/publicat.htm

http://www.worldmall.com/erf/lectures.htm

http://www.worldmall.com/erf/lectures/bones.htm

http://www.worldnet.de/dallas/storel.htm

http://www.wramc.amedd.army.mil/departments/wramcrad/bone/bonela.html

http://www.yamhillesd.k12.or.us/user/EwingYoung/hist.html

http://www.yamhillesd.k12.or.us/user/EwingYoung/index.html

http://wwwl.cc.emory.edu/PEDS/HEMONC/vega.htm

http://www2.ari.net/icare/cancertr.htm

http://www3.sympatico.ca/dave.poss/ewing.html
Alternative medicine has a substantial presence on the Internet, yet in our study we did not demonstrate significant referencing of alternative medicine. However, many alternative medicine Web sites have a home page with conventional general medical information. Surfing from that page will reveal alternative and complementary approaches rather than orthodox medicine. Limiting our evaluation to the page on which we landed from the search engine may have prevented us from accessing virtual stores of alternative medicine providers. Alternative providers also may focus their attention on the more commonly diagnosed diseases such as cancer of the breast or prostate, rather than Ewing sarcoma. Investigations currently are underway to evaluate this hypothesis. Had we performed our study by searching therapies, rather than by searching a disease, we would have found abundant information regarding such alternative medicines as hydrazine sulfate, shark cartilage, and coffee enemas.

The Internet has the potential to be helpful to both physicians and patients. Volumes of appropriate, accurate, and peer-reviewed information contained on Web pages are present, and previous difficult information distribution issues now can be relieved. The Internet can be a powerful, positive partner to the health care provider in patient education. Better health care results when patients are more involved with their treatment choices, more informed regarding their disease, and more invested in their health care.

Based on our experience, we have made the following recommendations. Healthcare providers need to remain open-minded and not feel threatened when patients arrive in the office with reams of information downloaded and printed from the Internet. We should be unafraid to explore new information discovered by patients, and recognize that this is not a challenge to our authority but rather an effort by patients to understand their disease. In the course of events, we should anticipate that patients occasionally will come armed with legitimate information we have not yet seen ourselves. The most productive course of action is to evaluate this information with the patient and recognize the opportunity for our own edification.

Physicians and other health care workers also must take the lead in helping patients to understand the variability of Web page postings and the possibility of misinformation. Education regarding the peer review process will help patients learn its importance in critically evaluating medical information. As patients understand the rigorous standards applied to medical and scientific journals, they will be able to contrast those information sources with anecdotal or unsub- 
stantiated postings from the Internet. Physician involvement with mechanisms currently being developed for rating health information on the Internet will provide an additional avenue for the identification of appropriate Internet information sources.

Alternative and complementary medicine exposure on the Internet must not be discounted. The Internet has brought a new opportunity to promoters of alternative medicine, allowing free advertisement with few restrictions. Open-ended questions and a nonjudgmental attitude regarding complementary medicine information retrieved from the Internet are the best tools to encourage patients to discuss their questions, concerns, and findings, and to permit discussion regarding the role that complementary medicine, along with conventionally tested orthodox medicine, may play in their care.

Finally, we may be able to best help our patients by reviewing relevant Web sites in our areas of expertise and making specific Web site recommendations to patients. At the University of Michigan Comprehensive Cancer Center, we have created a mechanism for physician review of medical information Web sites that we believe are appropriately recommended to patients. Health care providers with expertise in specific areas review Web sites carefully and sort them by specific diagnoses prior to listing them on the Cancer Center Web site as a source of additional information.

\section{CONCLUSIONS}

Although misleading or inaccurate information may be present on a small number of Web pages, the potential effects such postings may have on vulnerable patients is of concern. In addition, inaccuracies may be contradictory to the information given by the physician, creating patient doubt and distrust.

We recommend that physicians maintain an open mind regarding searches done by patients and questions raised by those searches. We suggest that physicians take an active role in identifying or creating accurate patient information Web sites and educate the lay public regarding variations in the quality of information and the contribution of the peer review process.

Computer literacy and an Internet connection must be a part of postgraduate physician education to enable us to best help our patients. The reality is that the Internet is here, growing, and will play an ever increasing role in the care of our patients. The best approach to coping with this reality is to be proactive and to recognize the opportunities that the Internet can provide for improvement of patient care.

\section{REFERENCES}

1. Treese, W. The Internet Index. Available from URL: http:// www.openmarket.com/intindex/98-05.htm [Accessed November 20, 1998].

2. Wulkan ML, Smith SD, Whalen TV, Hardin BD. Pediatric surgeons on the Internet: a multi-institutional experience. J Pediatr Surg 1997;32(4):612-4.

3. Lowes RL. Here come the patients who've studied medicine on-line. Med Econ 1997;74(2):175-84.

4. Ferguson T. Health online and the empowered medical consumer. Jt Comm J Qual Improv 1997;23(5):251-7.

5. American Medical Association Manual of style. 8th ed. Baltimore: Williams \& Wilkins, 1989.

6. Relman AS. The Ingelfinger rule. N Engl J Med 1981;305: 824-6.

7. Guarding the guardians: research on editorial peer review. Selected proceedings from the First International Congress on Peer Review in Biomedical Publication, May 10-12, 1989, Chicago, Ill. JAMA 1990;263:1317-441.

8. Day RA. How to write and publish a scientific paper. 3rd ed. Phoenix, AZ: Oryx Press, 1988.

9. Glode LM. Cancer information on the World Wide Web. J Clin Oncol 1996;15:29-33.

10. Netscape Netcenter Net Search. Available from URL: http:// home.netscape.com/escapes/search/ntsrchrnd-3.html [Accessed November 29, 1998].

11. Stokes ME, Davis CS, Koch GG. Categorical data analysis using the SAS system. Cary, NC: SAS Institute Inc., 1995.

12. DeVita VT, Hellman S, Rosenberg SA, editors. Cancer: principles and practice of oncology. 5th ed. Philadelphia: JB Lippincott, 1997.

13. Pealer LN, Dorman SM. Evaluating health-related Web sites. J Sch Health 1997;67(6):232-5.

14. Jadad AR, Gagliardi A. Rating health information on the Internet: navigating to knowledge or to Babel. JAMA 1998; 279(8):611-4.

15. Burgert EO Jr., Nesbit ME, Garnsey LA, Gehan EA, Herrmann J, Vietti TJ, et al. Multimodal therapy for the management of nonpelvic, localized Ewing's sarcoma of bone: intergroup study IESS-II. J Clin Oncol 1990;9:1514-24.

16. Challis DE, Johnson JM, Kennedy DS. Fetal anomaly, the Internet and the "informed" patient: a dangerous combination [letter to the editor]. Ultrasound Obstet Gynecol 1996;8: 68 . 